\title{
CONCEPT AND RATIONALE OF EVOLUTIONARY BARLEY BREEDING UNDER CLIMATE CHANGE IN JORDAN
}

\author{
Nawal Al-Hajaj ${ }^{1 凶}$, Omar Kafawin ${ }^{2}$ \\ Field Crop Directorate, National Center for Agriculture Research, Jordan. \\ ${ }^{2}$ Horticulture and Crop Department, Faculty of Agriculture, Jordan University, Jordan.
}

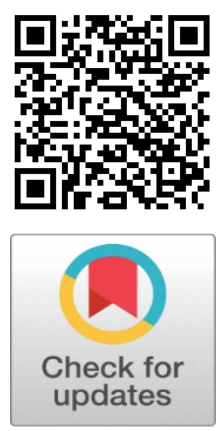

Received 15 July 2021

Accepted 30 July 2021

Published 31 August 2021

\section{CorrespondingAuthor}

Nawal Al-Hajaj,nawal@narc.gov.jo

DOI

10.29121/granthaalayah.v9.i8.2021. 4122

Funding: This research received no specific grant from any funding agency in the public, commercial, or not-for-profit sectors.

Copyright: (C) 2021 The Author(s). This is an open access article distributed under the terms of the Creative Commons Attribution License, which permits unrestricted use, distribution, and reproduction in any medium, provided the original author and source are credited.

\section{ABSTRACT}

In this study, we reviewed the climate changing and the impact on crop production, and evolutionary breeding as adaptation key to crop resilience. The increasing climate change impact on the agriculture system has renewed interest to the broadest possible germplasm base for a resilient and sustainable food system. Heterogeneous populations developed through evolutionary plant breeding could be the ideal solution to reduce the effects of environment variability on cereal crop planted under low-input conditions. The study assessed the genetic basis of adaptation of a barley population which evolved in different rainfed locations and years in Jordan without any human selection as suggests model of plant breeding strategy to improve food security, nutrition, income and resilience of smallholder farmers in the dryland regions in the climate change scenarios. The study suggests that the breeder can shift the undesirable traits in evolutionary populations by practicing individual selection for specific adaptations, or individual selection from populations showing wide adaptations and high stability. On the other hand, the breeder can overcome the undesirable traits by keeping the highest variations within the population by seed sieving to remove small seed and plant mowing for tallest head.

Keywords: Barley, Climate Change, Evolutionary Population, Crop Adaptation, Crop Resilience.

\section{INTRODUCTION}

The Poaceae family (grasses) evolved 50-70 million years ago (Mya) Huang et al.(2002) Wang et al. (2011) and wheat, barley and oats grouped under the sub-family Pooideae which diverged around 20 Mya Inda et al. (2008), that found in the Fertile Crescent in the human Neolithic sites, which are dated to _8500 calibrated years (cal.) B.C. Badr et al. (2000),Diamond (2002), Salamini et al. (2002) Morrell et al. (2003), Willcox G. (2005),Feldman and Kislev (2007). The Fertile Crescent includes part of Jordan, Palestine, Lebanon, Syria, Southeastern Turkey, Iraq and western Iran. Barley (Hordeum vulgare L.), is one of the most important and earliest crops in Neolithic agriculture El-Hashash and El-Absy (2019), and barley grains have been found at various archaeological sites in the Fertile Crescent Diamond, J.(1998), Wang et.al (2011). Moreover, the Jordan valley in the southern part of the Fertile Crescent has the highest probability where the first domestication of barley may have taken place as suggested by experimental evidence Badr et al. (2000), Pankin et al. (2018). Hordeum spontaneum C. Koch is the barley wild relative, and in modern taxonomy, H. vulgare L. and 
H. spontaneum C. Koch, as well as Hordeum agriocrithon $\mathrm{A}^{\circ}$ berg, are considered subspecies of H. vulgare Bothmer and Jacobsen. (1985).

The greatest gigantic evolutionary experiment is the domestication of plants and animals, characterized by adaptation and speciation, and generating incipient species Darwin (1905). Cereal germplasm was domesticated through heavy selection pressure against unfavorable alleles related to time of flowering, naked seeds, rachis brittleness, and the size of seed traits Konishi et al. (2006), Pourkheirandish and Komatsuda (2007), Page and Chapman (2021). 20-30 years would be enough complete barley, einkorn and emmer wheat domestication under rudimentary farming practices, where it should be a rapid event Honne and Heun (2009), Peng et al. (2011). Spring barley type is a key of evolution event for postdomestication come from a predominantly winter ancestral state, which spread of temperate cereals Cockram et al. (2007), Marzougui (2021). Domestication produces cultivars characterized by human-dependency, and surviving only under human agricultural practices to meet his needs Gustafson et al. (2009), Nevo (2011). Therefore, the populations known as "landraces" are the first identified old breeding materials from domestication process Berthaud et al. (2001).

Barley (Hordeum vulgare ssp. vulgare) is cultivated globally, but its decrease in importance as food grain was due, in part, to the increased importance of wheat and rice. In recent times, 55\%- $60 \%$ of the barley crop has been used for feed, 30\%-40\% for malt, $2 \%$ - 5\% for food, and about $5 \%$ for seed Ullrich (2010). Barley subsequent wide migration provides outstanding evidence of adaptation to multi environments, agro-ecologies and uses Dawson et al. (2015). Barley is the predominant crop in the low-rainfall areas of the Middle East Hazell (2018), and is considered as one of the most important cereal crops in the Fertile Crescent, grown on around 5 million hectares Ceccarelli and Grando (2000). Barley landraces are mostly cultivated in marginal land, low-input system, and drought stress environment Ceccarelli (1984), Kumar et al. (2020), because of their heterogeneity and diversity provide stability of good yield in highly variable environments Ceccarelli (1994), Ceccarelli (1996), Azeez et al. (2018). Thus, the low-input or organic farming systems require a specific crop characteristic, for this reason they might have disappeared in the modern breeding materials targeted to high-input conditions Lammerts Van Bueren et al. (2005), Lammerts Van Bueren et al. (2011), Jalata (2011), Torricelli et al. (2014)

Adaptation is the key of Darwinian evolution outcome, that termed natural selection Diniz-Filho and Bini (2019), and heritable variation is the heart of evolution process. Improved varieties have limited capacity to evolve in response to adverse environmental conditions due to their genetic uniformity, and this is the opposite of what it has been done for millennia by the farmers. Furthermore, the unpredictable environmental fluctuations will dramatically increase due to climate change Murphy et al. (2013). Ceccarelli et al. (2013) emphasized that climate changes are a moving target for plant breeding. Evolutionary plant breeding (EBP), is the right strategy to deal with such challenge, while at the same time maintain and increase the agricultural biodiversity. In evolutionary populations (EP) of selfpollinating cereals, the natural selection operating upon the heterogeneous mixture of genotypes over generations and across environments and traits positively correlated to reproductive capacity, which increases over the time Suneson (1956), Allard and Hansche (1964).

Jordan is located about $80 \mathrm{~km}$ to the East of the Mediterranean Sea with a predominantly Mediterranean climate; hot and dry summers, and wet and cool winters. Jordan is also characterized by three distinct ecological systems: (i) the Jordan Valley which forms a narrow strip located below the mean sea level, and has 
warm winters and hot summers with irrigation mainly practiced in this area; (ii) the western highlands where rainfall is relatively high and climate is typical of Mediterranean areas; and (iii) the arid and semiarid inland to the east (estimated to cover over $80 \%$ of the total area), known as the "Badia", where the annual rainfall is below $50 \mathrm{~mm}$. The spatial variation of precipitation is high and characterized by a general decrease from west to east and from north to south: temperature shows the same trend. Generally, the amount of rainfall and climatic conditions of the country do not support good rainfed agriculture. The rainfed agricultural zone is lying in areas where rainfall exceeds 250 millimeters although cereals production might be occurred in some areas where rainfall is between 200 and 250 millimeters (Map 1). Barley is cultivated in area where average rainfall is between $150 \mathrm{~mm}$ to $300 \mathrm{~mm}$; therefore, barley cultivation is facing challenges with more dry cycles and more frequent drought seasons, small farmers and herders are the ones who are the most affected. Finally, a number of studies emphasized the adverse effects of climate change in Jordan, where precipitation would be significantly decreased with a reduction in frequency and duration of rainy days as shown in Map 2, whereas temperature would be significantly increased Black (2009), Saba et al. (2014), Atashi et al. (2020). This will cause a reduction in crop yield and will threaten livestock sector.

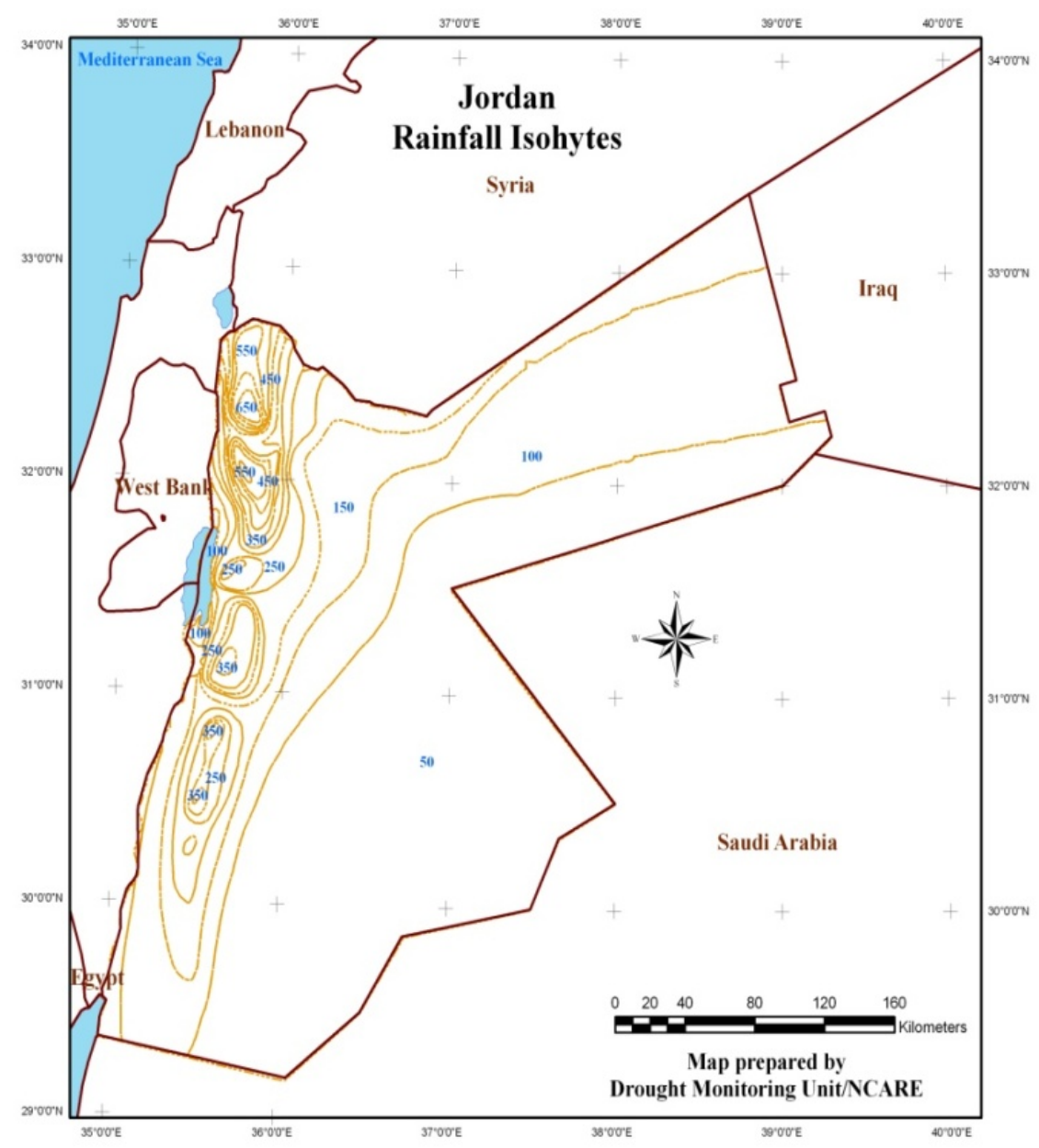

Map 1 Jordan rainfall Isohyets 


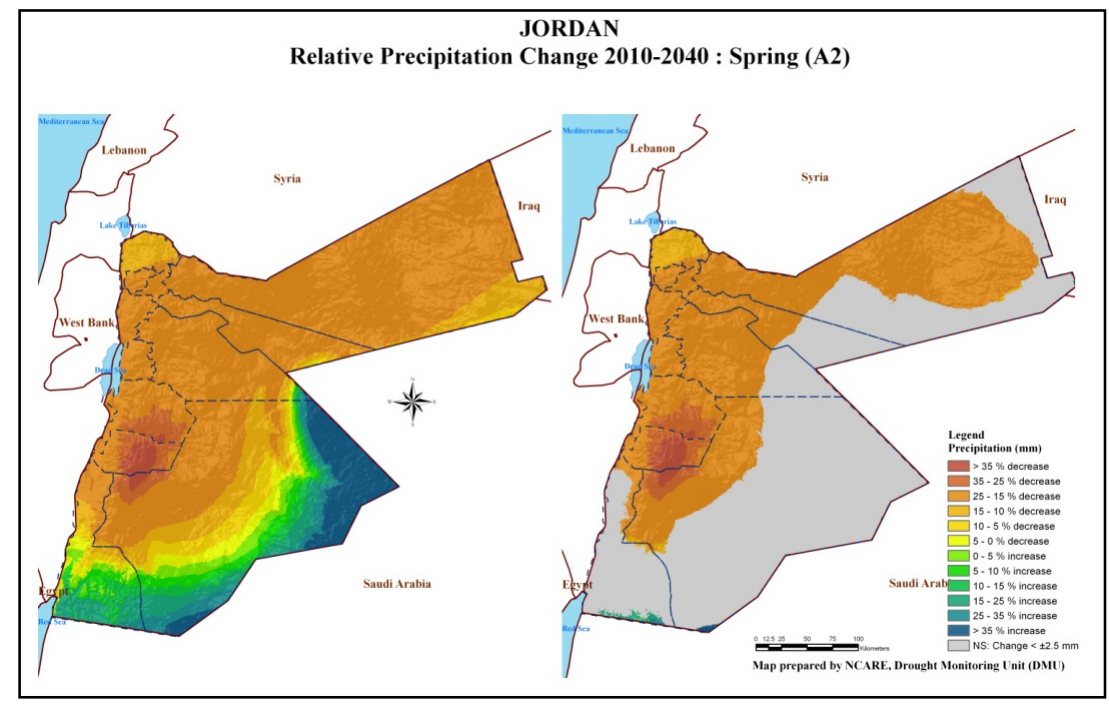

Map 2 Projected relative change map of Precipitation (2010 -2040) Saba et al. (2014)

Climate change effect renewed the interest in evolutionary breeding, which is based on a mass selection technique in heterogeneous populations of the crop Murphy (2005). A strong support to evolutionary plant breeding comes from the work of Morran et al. (2009) who proved that the adaptation of outcrossing population to environmental changes is more rapid than self-fertilizing organisms, therefore the majority of plants and animals reproduce by outcrossing as opposed to selfing Crow (1992), Schlaepfer et al. (2018). However, the self- pollinated crops even with outcrossing rates lower than 0.05 will be able to adapt to stress environments, such as barley and wheat (outcrossing rates as high as 0.07 , and 0.035, respectively) Morran et al. (2009), Wright et al. (2013). Thus, different experiment provides a strong justification for evolutionary plant breeding to both self- and cross-pollinated crops.

\section{CLIMATE CHANGE IN JORDAN}

The global carbon $\mathrm{CO} 2$ increased significantly in the atmosphere because of human activity, and our climate was affected negatively at an alarming and accelerating rate IPCC (1996), IPCC (2001). The landmark Fourth Assessment Report of the Intergovernmental Panel on Climate Change IPCC (2007a) concluded definitively that "[w]arming of the climate system is unequivocal" and goes to define a certain exception of pervasive effects of future climate change. One of the projections to the year 2100 was expected increase of CO2 emissions by $400 \%$ and the concentrations of $\mathrm{CO} 2$ atmospheric by 100\% (Figure 1, modified from Cline, 2007) Ceccarelli et al. (2013).

The future and current climate change in the Middle East study related to precipitation suggested a drying weather also the dominant precipitation mechanism will be from directly driven by storm tracks to having a greater leading by upslope flow of moist air masses Evans (2010). Evans (2008) revealed from 18 global climate models that Middle East rainfall is expected to decrease significantly by the end of the 21st century. On the other hand, the future eastern Mediterranean region climate scenario suggests that the rainy season will become significantly 
drier with reduction of the frequency and duration of its events, with potentially negative impact on the population IPCC (2007), Black (2009). These changes may be associated with decreased precipitation and increased evaporation, and water availability reduction in southern Europe and the Mediterranean as a result to changes of the Mediterranean storm track strength Pinto et al. (2007), Mariotti et al. (2008). Furthermore, Kitoh et al. (2008), concluded, based on a high-resolution global climate model in the Middle East, which the Fertile Crescent will disappear due to unbalance between precipitation and evaporation equation Demircan et al. (2017). The annual discharge will decrease significantly (29 - 73\%) in Euphrates River, as the stream flow in the Jordan River will. The heavy hourly and daily precipitation frequency will increase in the future: the hourly heavy precipitation will increase by $99.9 \%$, while the value of hourly precipitation will increase by $7 \%$ in the near future and by $21 \%$ at the end of the 21 st century Kitoh et al. (2009).

Jordan had severe dry years during the last 30 years (1901- 2010). Moreover, the future precipitation projection (2010-2025) assumed moderate reduction up to 15 days of the total precipitation period, the reduction will be from 15-30 days in north and central areas, and few areas will face reduction up to 30 days Saba et al. (2014). These results are consistent with published work by Black (2009) about Mediterranean storm track under future climate scenarios. According to vulnerability analysis carried by the National Communication (TNC) to UNFCCC (JTNC report 2014), Eastern and Southern areas and the North mountainous areas in Jordan are expected to have the highest exposure to the impact of climate change; as the vegetation type is the highest sensitivity component for climate change, therefore the impact of climate change expected to be in the northern highlands and across the Middle areas in Jordan especially the Jordan Valley. The annual precipitation trend deceases significantly with time at a rate of $1.2 \mathrm{~mm}$ per year. The decreased was recorded mostly in the western part of the country. Simultaneously, the air temperature tends to increase significantly by $0.02,0.01$, and $0.03{ }^{\circ} \mathrm{C} /$ year, for mean, maximum and minimum, respectively. Falloon et al. (2007) emphasized the above result by his prediction that the rainfall will decrease by around $26.6 \mathrm{~mm}$ and the temperature will increase by around $6.5^{\circ} \mathrm{C}$ during $2000-2100$.
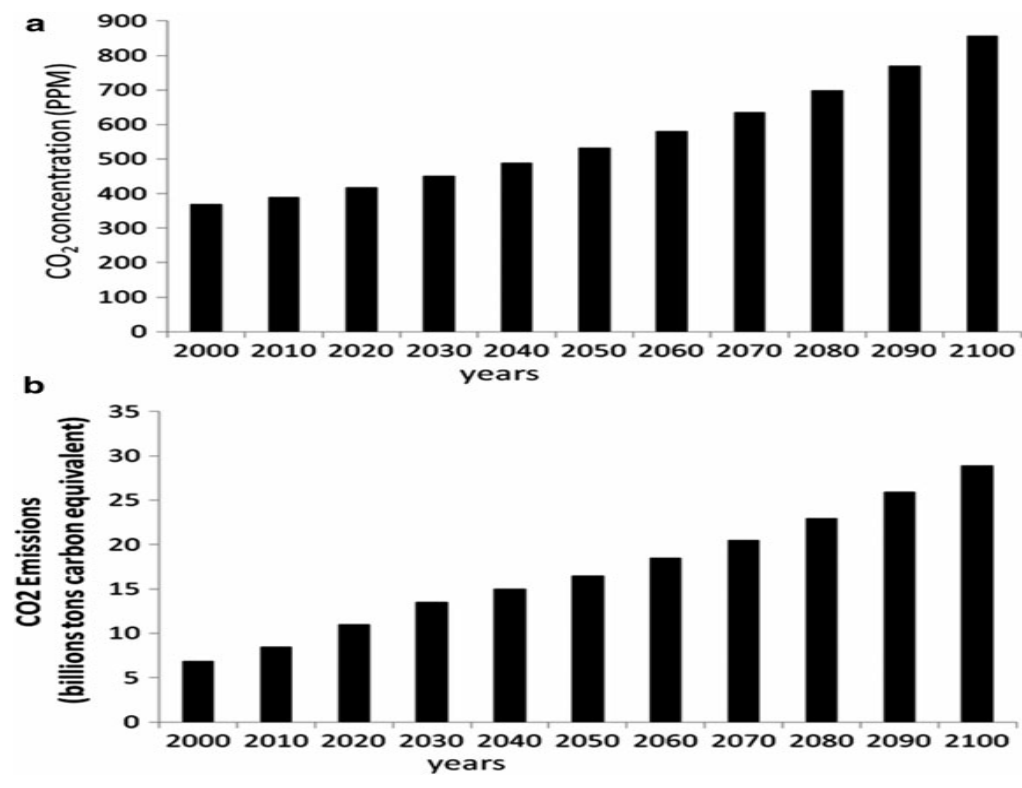

Figure 1 Projected atmospheric CO2 concentration in parts per million CO2 (a) and projected emission in billion tons carbon equivalent (b) (modified from Cline, 2007) 


\section{CLIMATE CHANGE AND CROP RESILIENCE}

An increasing sense of urgency characterizes the local and global dialogue on climate change. Many evidence emphasized climate change existence, where the dry and wet regions will become drier or wetter as response to warming, respectively Durack et al. (2012), Yang et al. (2019). On the other hand, some studies have predicted the potential of climate change impact on increased extinction rate in natural ecosystem Pecl et al. (2017), Sintayehu (2018). As the agriculture sector is extremely vulnerable to climate change, climate change will adversely impact on food production and quality, Atkinson et al. (2008). The ecologically vulnerable zone included the arid and semiarid zones, and the mountains and hills that characterize by low- poor resources, highly heterogeneous, and where the majority of the world's rural poor live Conway et al. (1997).

The International Food Policy Research Instituteestimated a 30\%, 47\%, and $20 \%$ crop yields reduction (to the year 2050) for rice, maize, and wheat, respectively, due to climate change Nelson et al. (2009). Lobell et al. (2008) validated this result.Adaptation to climate change is defined by the Intergovernmental Panel on Climate Change as "any adjustment in natural or human systems in response to actual or expected climatic stimuli or their effects, which moderates harm or exploits beneficial opportunities." IPCC (2007). Agriculture adaptation to climate change can include spontaneous adaptations FAO (2007) to encompass research improvement, genetic improvement, increase crop diversity resulting in improved crop performance under climate change Newton (2009).

Ongoing climate change included droughts and other anticipated changes which has potent selective factors Franks et al. (2007), that can impose natural selection to buffer species using phenotypic plasticity to tolerate the habitat degradation based on evolutionary shifts McCairns et al. (2016). Theses shift provide good opportunities to study how natural populations undergo adaptive evolution. Farmers since millennia used his way to act the natural selection in harsh environments to make autonomous adaptations on a crop, such as barley in the Fertile Crescent Ceccarelli and Grando (2000), Ceccarelli et al. (2007).

\section{IMPORTANCE AND UTILIZATION OF EVOLUTIONARY PLANT BREEDING}

Evolutionary breeding (EB) generates plant populations defined as Suneson, 1956 as 'core features are a broadly diversified germplasm, and a prolonged subjection of the mass of the progeny to competitive natural selection in the area of contemplated use'. It's created through saving and re-sowing seed in bulking over several plant generations, therefore as Darwinian selection where the plant population reproductive fitness physical mixing will be gradually increases Döring et al. (2011), Lammerts et al. (2018). Evolutionary Plant Breeding can make use of populations such as Composite Cross Populations (CCPs) or of varietal mixtures; the difference is that CCPs are created by crossing while mixtures are created by mixing seed of existing varieties Döring et al. (2011). Therefore, CCPs and varietal mixtures have been named 'modern landraces' where they are similar to traditional landraces on creating and purpose of creating Carolina et al. (2005), Murphy et al. (2005).

The idea of plant evolutionary breeding is not new. Harlan and Martini created the composite cross (CC) method for breeding barley in 1929 Harlan and Martini 
(1929). The method relies on bulking the F1 progenies to generate a heterogeneous population of recombinant genotypes; where F1 progenies obtained by hybridization of diverse origin varieties and genetic make-up. In 1956, 'evolutionary plant-breeding method' idea has been improved and proposed formally by Suneson (1956). Using this breeding method, nine barley CCs were registered by Suneson, (1969), and intended to be used as parental populations (PPs) to generate a new variety, and also as research material for the population genetics studies Suneson, (1956). Recombination and segregation in the populations is the key for the success of such a breeding method, and the extent to survival mass-propagated populations over many generations is positively correlated with agricultural value Allard and Hansche (1964).

The key science in improving crop production is plant breeding, which has contributed an estimated 50\% to increased agricultural productivity Ceccarelli (2015), Qaim, 2020). High and stable crop yield are an important goal in plant breeding Johnson (1977), Lammerts et al. (2018). In March 1968, "Green Revolution" term coined by William S. Gaud indicated a development strategy in which mainly self-pollinated crops varieties were produced commercially with high genetic uniformity, due to their high production and wide geographic adaptation Soliman and Allard (1991), Ceccarelli (2009), Pingali (2017), rather than wide 'environmental' adaptation Ceccarelli (2009). In addition, these varieties had poor performance under marginal environments or without the external inputs Ceccarelli (1996), Mustafa et al. (2019). Therefore, around 1.4 billion people who lives in marginal agricultural environments and limited use of external inputs, and poor farmers are depending on traditional agricultural systems Ceccarelli (1996), Murphy (2005). Modern plant breeding produces a small number of varieties for major crop and for high input conditions, with a reduction in agrobiodiversity and a threat to global food security for some crop cultivated in the regions affected by climate change with a negative impact on agriculture Nelson et al. (2009), Ali et al. (2017).

Since a few decades, the interest for agrobiodiversity has started to be "rediscovered" all over the world, and is still growing up, and mainly for organic and low input agriculture. Diversity is recognized as important s for disease and pest management, to mitigate abiotic stresses, and to increase productivity and longterm stability of the system Hajjar et al. (2008), Morales-Castilla et al. (2020). Serpolay-Besson et al. (2014) conclude OPVs (open pollinated varieties) are evolving quickly due to their genetic heterogeneity under the combined effect of human and natural mass selection in organic and low input conditions. This result was emphasized by Pixley (2006), in comparing yields of OPVs (7\%) and hybrids $(20 \%)$ in a meta-analysis, however this difference was reduced in the "marginal environments" where the performance of heterogeneous varieties was relatively better. These environments can be described by: high variability in mean of time and space, low fertility, and subjected to high stress (drought, cold...etc) in general Ceccarelli (1994).Ceccarelli and Grando (2000) validate this result, where natural selection act in harsh environments on a crop as example the Fertile Crescent, where farmers cultivate predominantly heterogeneous barley populations rather than a small number of genotypes with superior adaptation. Here, the landraces carry a lesson about its structure; that represent an evolutionary approach to keep it survival and good performance under arid and semiarid conditions Schulze (1988), Lodhi et al. (2020). Interestingly, a study comparing barley landraces and modern cultivars showed that landraces yielded on average $60 \%$ more under stress, whereas modern cultivar yielded on average 14\% more when the stresses absent Ceccarelli (2015), Cantalapiedra et al (2017). 
EBP offers a great possibility of reconciling agro-biodiversity; also it can contribute to cropping systems development with yield stability and greater resilience in the environment variability Döring et al. (2011), Barot et al (2017). Despite Robert W. Allard and co-workers Allard and Adams (1969), Allard (1988), Jain and Allard (1966) make a prolific research about EBP, this technique has never been used in commercial breeding practice Phillips and Wolfe (2005). Frey and Maldonado (1967) suggested that the benefit of heterogeneous cereal population will be more obvious in resource-limiting environments Murphy et al. (2013), Merrick et al. (2020). Soliman and Allard (1991) validate this result by make a comparison between barley composite crosses with commercial cultivar across a range of marginal environments that showed significantly yield stability for CC. The most effective way to increase EP grain yield is by expose it to constant and directional selection pressures Degago and Caviness (1987), Murphy et al. (2013).

Ongoing climate change can impose natural selection on certain ecologically important traits that in turn will be affected the ecological dynamics of many plant species. The consequence of operating the natural selection on phenology, imposed by climate change, is evolutionary shift based on genetic Franks et al. (2007), Bemmels and Anderson (2019). Crops phenology is very important in relation to drought tolerance allowing the crops to complete their life cycle before the onset of drought Baum et al. (2003). Therefore, it's one of the main adaptations traits to adapt to climate change. In addition, the theory of selection shows that decentralized (i.e., selection conducted directly in the target environment) is more efficient than centralized in terms of response to selection Simmonds (1991), Ceccarelli (2015).In participatory plant breeding (PPB), defined as collaboration between farmers and scientists in plant breeding Ceccarelli and Grando (2007), for the selection of high yielding varieties, the selection process is carried out in individual farmers fields Ceccarelli et al. (2000). This effective result has been shown on major cereal crops varieties selection, including barley, maize, wheat, and rice Sthapit et al. (1996), Bänziger and Cooper (2001),Ceccarelli et al. (2001), Witcombe et al. (2003), Thapa et al. (2009), Bachmann (2010), Medina (2012). Participatory Plant breeding (PPB)is another pathway to reconciling agrobiodiversity with a rapid moving of varieties both in time and space, making plant breeding more efficient by increasing the adoption ratio of varieties, selection gains, and the benefit/cost ratio Ceccarelli et al. (2013), Madalla (2021).

Evolutionary participatory breeding (EPB) is a method that merges farmer participatory breeding with evolutionary breeding to develop high-yielding of desired quality cultivars and disease-resistant, with maintaining their ability to adapt to environment fluctuations conditions through a high degree of genetic variation Murphy et al. (2005), Ceccarelli and Grando (2019). In the actual climate change scenario, evolving crop populations can be a source of useful genetic diversity conservation and a source of genes for breeding purposes, on the contrary of modern plant breeding purposes Ceccarelli et al. (2013) and this contradiction will be appearing obviously if climate change is considered.

\section{CASE STUDY OF EVOLUTIONARY PLANT BREEDING IN JORDAN}

The study assesses the genetic basis of adaptation of a barley population which evolved in different rainfed locations and years in Jordan; provide the national breeding program and farmers with a continuous flow of novel genetic diversity occurring within an evolutionary population. The reports on analysis of twenty-one 
agro-morphological traits recorded on five populations that evolved during six years in five low-input locations without any human selection. The experiments were conducted in five low-input locations, namely Ramtha east and west, Mushaqer east and west, and Ghweir. Each experiment included each of the five evolutionary populations with their evolving generations and five local controls. The experiments were conducted under farmer fields' conditions using partially replicated row-column design.

The twenty-one agro-morphological traits were analyzed using bi-dimensional spatial analysis, cluster analysis, multivariate approach and stability analysis. Seed quality improved in the sixth generation (G6) of evolution compared with the original population (G0); the improvement differed according to the location. The results showed that natural selection was operating on the populations for some of the traits namely plant height, number of seed per spike, and seed size. The different generations were superiors to the best local control in at least one of the yield traits namely spike weight, number of seeds per spike, weight of seeds in a spike, and grain weight.

The analysis among populations tested together in the five locations showed that two to four morphological clusters were identified by cluster analysis in each location. The largest populations number were grouped in one cluster compared with the rest of the clusters which were characterized mainly by heavier spike with higher number of seed per spike, tall plant, long peduncle. Interestingly, the frequency of the population divided upon to control architecture, showing good plant and spike characters for six row type, and good grain yield for two row types. Stability analysis based on high mean and low coefficient variations, showed a number of populations from Ramtha west, Mushaqer west and Ghweir having high grain yield and high stability in most of the locations.

The analysis of each evolving populations tested in the five locations showed that two to three morphological clusters were identified by cluster analysis for each population. The populations were grouped together in one cluster, except in Mushaqer east, compared with the rest of the clusters which were characterized mainly by good grain yield, and by a positive expression of at least one of the yieldrelated traits. The grain yield fluctuated during the evolution of these populations. Stability analysis showed that Ramtha west and Mushaqer east populations were highly adapted to their low input locations but not stable, and Ramtha east, Mushaqer west, and Ghweir had stable populations over all location from their last generation.

The study suggests that the breeder can shift the undesirable traits in these populations by practicing individual selection in each location for specific adaptations, or individual selection from populations showing wide adaptations and high stability. On the other hand, the breeder can overcome the undesirable traits by keeping the highest variations within the population by seed sieving to remove small seed and plant mowing for tallest head.

\section{REFERENCES}

Ali, S., Liu, Y., Ishaq, M., Shah, T., Ilyas, A., \& Din, I. U. (2017). Climate change and its impact on the yield of major food crops: Evidence from Pakistan. Foods, 6(6), 39. Retrived from https://doi.org/10.3390/foods6060039

Allard, R.W. Adams, J. (1969), Population studies in predominantly self-pollinating species. XIII. Intergenotypic competition and population structure in barley 


$\begin{array}{lcccccc}\text { and wheat. Am. Nat., } & \text { 103, } & \text { 621-645. } & \text { Retrived } & \text { from } \\ \text { https://doi.org/10.1086/282630 } & & & & \end{array}$

Allard, R.W. and Hansche P.E, (1964), Some parameters of population variability and their implications in plant breeding. Advances in Agronomy 16: 281-325. Retrived from https://doi.org/10.1016/S0065-2113(08)60027-9

Allard, R.W. (1988), Genetic changes associated with the evolution of adaptedness in cultivated plants and their wild progenitors. J. Hered. 79, 225-238. Retrived from https://doi.org/10.1093/oxfordjournals.jhered.a110503

Atashi, N., Rahimi, D., Al Kuisi, M., Jiries, A., Vuollekoski, H., Kulmala, M., ... \& Hussein, T. (2020). Modeling Long-Term Temporal Variation of Dew Formation in Jordan and Its Link to Climate Change. Water, 12(8), 2186. Retrived from https://doi.org/10.3390/w12082186

Atkinson MD, Kettlewell PS, Poulton PR, Hollins PD (2008) Grain quality in the Broadbalk Wheat Experiment and the winter North Atlantic Oscillation. Retrived from https://doi.org/10.1017/S0021859608007958

Bänziger, M., Cooper, M. (2001), Breeding for low input conditions and consequences for participatory plant breeding examples from tropical maize and wheat. Euphytica 122:503-519. Retrived from https://doi.org/10.1023/A:1017510928038

Azeez, M. A., Adubi, A. O., \& Durodola, F. A. (2018). Landraces and crop genetic improvement. In Rediscovery of Landraces as a Resource for the Future. IntechOpen. Retrived from https://doi.org/10.5772/intechopen.75944

Bachmann, L. (2010), Farmer-led participatory plant breeding. Methods and impacts. The MASIPAG farmers Network in the Philippines. Institut National de la RechercheAgronomique (INRA), Paris, pp 119-122. Retrived from https://www.cabdirect.org/cabdirect/abstract/20123096437

Badr, A., Sch, R., Rabey, H.E., Effgen, S., Ibrahim, H.H., Pozzi, C., Rohde, W. and Salamini, F. (2000), On the origin and domestication history of barley (Hordeumvulgare). Molecular Biology and Evolution, 17(4), pp.499-510. Retrived from https://doi.org/10.1093/oxfordjournals.molbev.a026330

Barot et al., S., Allard, V., Cantarel, A., Enjalbert, J., Gauffreteau, A., Goldringer, I., ... \& Porcher, E. (2017). Designing mixtures of varieties for multifunctional agriculture with the help of ecology. A review. Agronomy for sustainable development, 37(2), 13. Retrived from https://doi.org/10.1007/s13593017-0418-X

Baum, M., Grando, S., Backes, G., Jahoor, A., Sabbagh, A., Ceccarelli, S. (2003), QTLs for agronomic traits in the Mediterranean environment identified in recombinant inbred lines of the cross 'Arta' x H. spontaneum 411. TheorAppl Genet 107:1215-1225. Retrived from https://doi.org/10.1007/s00122-003-1357-2

Bemmels, J. B., \& Anderson, J. T. (2019). Climate change shifts natural selection and the adaptive potential of the perennial forb Boechera stricta in the Rocky Mountains. Evolution, 73(11), 2247-2262. Retrived from https://doi.org/10.1111/evo.13854

Berthaud, J., Cle'ment, JC., Empearire, L., Louette, D., Pinton, F., Sanou, J et al (2001), The role of local level gene flow in enhancing and maintaining genetic diversity. In: Cooper 162 HD, Spillane C, Hodgkin T (eds) Broadening the 
genetic base of crop production. IPGRI/FAO, Rome, pp 81-103. Retrived from https://doi.org/10.1079/9780851994116.0081

Black, E. (2009), The impact of climate change on daily precipitation . . http://onlinelibrary.wiley.com/doi/10.1002/asl.233/full

Bothmer , R., Von. and N, Jacobsen. (1985). Origin, taxonomy, and related species.Pp. 19-56 in D. C. RASMUSSON, ed. Barley.American Society of Agronomists, Madison, Wis. Retrived from https://doi.org/10.2134/agronmonogr26.c2

Carolina, T., Villa, C., Maxteda, N., Scholten, M., Ford-Lloyd, B. (2005), Defining and identifying crop landraces. Plant Genet.Resour. Charact. 3, 373-384. Retrived from https://doi.org/10.1079/PGR200591

Cantalapiedra, C. P., García-Pereira, M. J., Gracia, M. P., Igartua, E., Casas, A. M., \& Contreras-Moreira, B. (2017). Large differences in gene expression responses to drought and heat stress between elite barley cultivar Scarlett and a Spanish landrace. Frontiers in plant science, 8, 647. Retrived from https://doi.org/10.3389/fpls.2017.00647

Ceccarelli, S. (1984), Utilization of landraces and Hordeumspontaneumin barley breeding for dry areas. Rachis 3, 8-11.

Ceccarelli, S. (1994), Specific Adaptation and Breeding for Marginal Conditions. Euphytica, 77, 205-221. Retrived from https://doi.org/10.1007/BF02262633

Ceccarelli, S. (1996), Positive interpretation of genotype by environment interactions in relation to sustainability and biodiversity. In: Cooper $\mathrm{M}$, Hammers GL (eds) Plant adaptation and crop improvement. CAB Int/ICRISAT/IRRI, Wallingford/Andra Pradesh/Manila, pp 467-486.

Ceccarelli, S.S. (1996), Adaptation to low/high input cultivation. Euphytica 92:203214. Retrived from https://doi.org/10.1007/BF00022846

Ceccarelli, S., Grando, S. (2000), Barley landraces from the Fertile Crescent: a lesson for plant breeders. In: Brush SB (ed) Genes in the field: on-farm conservation of crop diversity. IPGRI/ IDRC/Lewis, Rome/Ottawa/Boca Raton, FL, pp 5176.

Ceccarelli, S.,Grando, S., Tutwiler, R., Baha, J., Martini, AM., Salahieh, H., Goodchild, A., Michael, M., (2000), A methodological study on participatory barley breeding. I. Selection phase. Euphytica 111:91-104. Retrived from https://doi.org/10.1023/A:1003717303869

Ceccarelli, S., Grando, S., Bailey, E., Amri, A., El-Felah, M., Nassif, F., Rezgui, S., Yahyaoui, A. (2001), Farmer participation in barley breeding in Syria, Morocco and Tunisia.Euphytica 122:521-536. Retrived from https://doi.org/10.1023/A:1017570702689

Ceccarelli, S. (2009), Evolution, plant breeding and biodiversity. Journal of Agriculture and Environment for International Development (JAEID), 103(1/2), pp.131-145.

Ceccarelli, S. and Grando, S. (2007), Decentralized-participatory plant breeding: an example of demand driven research. Euphytica, 155(3), 349-360. Retrived from https://doi.org/10.1007/s10681-006-9336-8

Ceccarelli, S.,Galie, A. and Grando, S. (2013), Participatory breeding for climate change-related traits. In Genomics and breeding for climate-resilient crops 
(pp. 331-376). Springer Berlin Heidelberg. Retrived from

https://doi.org/10.1007/978-3-642-37045-8_8

Ceccarelli, S. (2015), Efficiency of plant breeding. Crop Science, 55(1), 87-97. Retrived from https://doi.org/10.2135/cropsci2014.02.0158

Ceccarelli, S., \& Grando, S. (2019). From participatory to evolutionary plant breeding. In Farmers and Plant Breeding (pp. 231-244). Routledge. Retrived from https://doi.org/10.4324/9780429507335-15

Cline, WR. (2007), Global warming and agriculture: impact estimates by country. Peterson Institute for International Economics, Washington, DC, $250 \mathrm{p} \mathrm{,pp}$ 75-105.

Cockram, J., Jones, H., Leigh, FJ., O'Sullivan, D., Powell, W., Laurie, DA., Greenland, AJ. (2007), Control of flowering time in temperate cereals: genes, domestication, and sustainable productivity. J Exper Bot 58:1231-1244. Retrived from https://doi.org/10.1093/jxb/erm042

Conway, GR. (1997), The doubly green revolution. Penguin, London, 360 p.

Crow, J.F. (1992), An advantage of sexual reproduction in a rapidly changing environment. J. Hered. 83, 169-173. Retrived from https://doi.org/10.1093/oxfordjournals.jhered.a111187

Darwin, C. (1905), The variation of animals and plants under domestication. John Murray, London (popular edition in two volumes) 566 p. Retrived from https://doi.org/10.5962/bhl.title.84435

Dawson, I.K., Russell, J., Powell, W., Steffenson, B., Thomas, W.T. and Waugh, R., (2015), Barley: a translational model for adaptation to climate change. New Phytologist, 206(3), pp.913-931. Retrived from https://doi.org/10.1111/nph.13266

Degago, Y.,Caviness, C. (1987), Seed yield of soybean bulk populations grown for 10 to 18 years in two environments. Crop Sci 27:207-210. Retrived from https://doi.org/10.2135/cropsci1987.0011183X002700020014x

Demircan, M., Gürkan, H., Eskioğlu, O., Arabaci, H. and Coskun, M. (2017). Climate change projections for Turkey: three models and two scenarios. Turkish Journal of Water Science and Management, 1(1), 22-43. Retrived from https://doi.org/10.31807/tjwsm.297183

Diamond, J.(2002), Evolution, consequences and future of plant and animal domestication. Nature, 418(6898), 700-707. Retrived from https://doi.org/10.1038/nature01019

Diamond, J.(1998), Guns, germs and steel. Vintage, London.

Diniz-Filho, J. A. F., and Bini, L. M. (2019). Will life find a way out? Evolutionary rescue and Darwinian adaptation to climate change. Perspectives in Ecology and Conservation, 17(3), 117-121. Retrived from https://doi.org/10.1016/j.pecon.2019.06.001

Döring, T.F., Knapp, S., Kovacs, G., Murphy, K. and Wolfe, M.S., (2011), Evolutionary plant breeding in cereals-into a new era. Sustainability, 3(10), pp.19441971. Retrived from https://doi.org/10.3390/su3101944

Durack, PJ.,Wijffels, SE., Matear, RJ. (2012), Ocean salinities reveal strong global water cycle intensification during 1950 to 2000. Science 336:455-458. Retrived from https://doi.org/10.1126/science.1212222 
El-Hashash, E. F., \& El-Absy, K. M. (2019). Barley (Hordeum vulgare L.) breeding. In Advances in Plant Breeding Strategies: Cereals (pp. 1-45). Springer, Cham. Retrived from https://doi.org/10.1007/978-3-030-23108-8_1

Evans, JP. (2008), 21st century climate change in the Middle East.Climatic Change 92: 417-432. Retrived from https://doi.org/10.1007/s10584-008-9438-5

Evans, JP. (2010), Globalwarming impact on the dominant precipitation processes in the Middle East. Theoretical and Applied Climatology. 99(3):389-402 DOI 10.1007/s00704-009-0151-8. Retrived from https://doi.org/10.1007/s00704-009-0151-8

FAO (Food and Agriculture Organization). (2007), Adaptation to Climate Change in Agriculture, Forestry and Fisheries: Perspective, Framework and Priorities. Rome,Italy: Interdepartmental Working Group on Climate Change.

Falloon, P., Jones, C.D., Cerri, C.E., Al-Adamat, R., Kamoni, P., Bhattacharyya, T., Easter, M., Paustian, K., Killian, K., Coleman, K. and Milne, E., (2007), Climate change and its impact on soil and vegetation carbon storage in Kenya, Jordan, India and Brazil.Agriculture, ecosystems \& environment, 122(1), pp.114-124. Retrived from https://doi.org/10.1016/j.agee.2007.01.013

Feldman, M., Kislev, ME.(2007), Domestication of emmer wheat and evolution of free-threshing tetraploid wheat. Israel J Plant Sci 55:207-221. Retrived from https://doi.org/10.1560/IJPS.55.3-4.207

Franks, S.J.,Sim, S. and Weis, A.E., (2007), Rapid evolution of flowering time by an annual plant in response to a climate fluctuation. Proceedings of the National Academy of Sciences, 104(4), pp.1278-1282. Retrived from https://doi.org/10.1073/pnas.0608379104

Frey, K., Maldonado, U. (1967), Relative productivity of homogeneous and heterogeneous oat cultivars in optimum and suboptimum environments. Crop Sci 7:532-535. Retrived from https://doi.org/10.2135/cropsci1967.0011183X000700050037x

Gustafson, P., Raskina, O., Ma, X., Nevo, E. (2009), Wheat evolution, domestication, and improvement. In: Carver BF (ed) Wheat: science and trade. Wiley, Danvers, $\quad$ pp 5-30. from https://doi.org/10.1002/9780813818832.ch1

Hajjar, R., Jarvis, D.I. and Gemmill-Herren, B. (2008), The Utility of Crop Genetic Diversity in Maintaining EcosystemServices. A review.Agriculture, Ecosystems and Environment, 123, 261-270 . Retrived from https://doi.org/10.1016/j.agee.2007.08.003

Harlan, H. V. and Martini, M. L. (1929), Earliness in F1 barley hybrids. Journal of Heredity, 20(12), 557-560. Retrived from https://doi.org/10.1093/oxfordjournals.jhered.a103131

Hazell, P. (2018). Chapter Fifteen. Managing Drought Risks in the Low-Rainfall Areas of the Middle East and North Africa (7-5). In Case Studies in Food Policy for Developing Countries (pp. 185-194). Cornell University Press. Retrived from https://doi.org/10.7591/9780801466373-018

Honne, BI., Heun, M. (2009), On the domestication genetics of self-fertilizing plants. VegetHistArchaeobot 18:269-272. https://doi.org/10.1007/s00334-009-0213-y 
Huang, S.,Sirikhachornkit, A., Su, X., Faris, J., Gill, B., Haselkorn, R., Gornicki, P. (2002), Genes encoding plastid acetyl-CoA carboxylase and 3-phosphoglycerate kinase of the Triticum/Aegilops complex and the evolutionary history of polypoid wheat.ProcNatlAcadSci USA 99:8133-8138)ackage for education and data analysis. Palaeontologia Electronica 4, 1-9. Retrived from https://doi.org/10.1073/pnas.072223799

Inda, LA., Segarra-Moragues, Jose' Gabriel, Mu“llerJochen, Peterson Paul M, Catala'nPilar, (2008), Dated historical biogeography of the temperate LoHinae (Poaceae, Pooideae) grasses. Retrived from https://doi.org/10.1016/j.ympev.2007.11.022

IPCC (Intergovernmental Panel on Climate Change), (1996) Watson, R.T., Zinyowera, M.C.

IPCC (Intergovernmental Panel on Climate Change), (2001), Climate Change 2001, Impacts, Adaptation, and Vulnerability. Contribution of Working Group II to the IPCC Third Assessment Report (TAR). Cambridge University Press, Cambridge, UK.

IPCC (Intergovernmental Panel on Climate Change), (2007), Climate Change 2007: The Fourth Assessment Report of the Intergovernmental Panel on Climate Change. Cambridge, U.K.: Cambridge University Press. Retrived from https://doi.org/10.1017/CB09780511546013

IPCC. (2007), Fourth Assessment report: Working group II report "Impacts, Adaptation and Vulnerability", http://www.ipcc.ch/ ipccreports/ar4wg2.htm. [Accessed August 2009].

Jain, S.K., Allard, R.W. (1966), The effects of linkage, epistasis, and inbreeding on population changes under selection. Genetics, 53, 633-659. Retrived from https://doi.org/10.1093/genetics/53.4.633

Jalata, Z. (2011), GGE-biplot analysis of multi-environment yield trials of barley /Hordeiumvulgare L. genotypes insoutheastern Ethiopia highlands. International Journal of Plant Breeding and Genetics 5, 59-75. Retrived from https://doi.org/10.3923/ijpbg.2011.59.75

Johnson, G. (1977), Analysis of genotypic similarity in terms of mean yield and stability of environmental response in a set of maize hybrids. Crop Science, 17(6), pp.837-842. Retrived from https://doi.org/10.2135/cropsci1977.0011183X001700060005x

Kitoh, A., Yatagai, A., Alpert, P. (2008), First super-high-resolution model projection that the ancient "Fertile Crescent" will disappear in this century. Hydrological Research Letters 2: 1-4. Retrived from https://doi.org/10.3178/hrl.2.46

Kitoh, A.,Ose, T., Kurihara, K., Kusunoki, S. and Sugi, M. (2009), Projection of changes in future weather extremes using super-high-resolution global and regional atmospheric models in the KAKUSHIN Program: Results of preliminary experiments. Hydrological Research Letters, 3, pp.49-53. Retrived from https://doi.org/10.3178/hrl.3.49

Konishi, S., Izawa, T., Lin, SY.,Ebana, K., Fukuta, Y., Sasaki, T., Yano, M. (2006), An SNP caused loss of seed shattering during rice domestication. Science 312:13921396. Retrived from https://doi.org/10.1126/science.1126410 
Kumar, A., Verma, R. P. S., Singh, A., Sharma, H. K., \& Devi, G. (2020), Barley landraces: Ecological heritage for edaphic stress adaptations and sustainable production. Environmental and Sustainability Indicators, 6, 100035. Retrived from https://doi.org/10.1016/j.indic.2020.100035

Lammerts van Bueren, E. T., Struik, P. C., Eekeren, N. V., \& Nuijten, E. (2018). Towards resilience through systems-based plant breeding. A review. Agronomy for sustainable development, 38(42), 1-21. Retrived from https://doi.org/10.1007/s13593-018-0522-6

Lammerts Van Bueren, E. T., Jones, S. S., Tamm, L., Murphy, K. M., Myers, J. R., Leifert, C. and Messmer, M.M. (2011), The need to breed crop varieties suitable for organic farming, using wheat, tomato and broccoli as examples: a review. NJAS - Wageningen Journal of Life Sciences 58, 193-205. Retrived from https://doi.org/10.1016/j.njas.2010.04.001

Lammerts Van Bueren, E. T., Van AN Soest, L. J. M., DE Groot, E. C., Boukema, I.W. and Osman, A.M. (2005), Broadening the genetic base of onion to develop betteradapted varieties for organic farming systems. Euphytica146, 125-132. Retrived from https://doi.org/10.1007/s10681-005-0204-8

Lobell, DB., Burke, MB., Tebaldi, C., Mastrandrea, MD., Falcon, WP., Naylor, RL. (2008), Prioritizing climate change adaptation needs for food security in 2030. Science 319:607-610. Retrived from https://doi.org/10.1126/science.1152339

Lodhi, S. S., Maryam, S., Rafique, K., Shafique, A., Yousaf, Z. A., Talha, A. M., ... \& Amir, R. (2020), Overview of the prospective strategies for conservation of genomic diversity in wheat landraces. In Climate Change and Food Security with Emphasis on Wheat (pp. 293-309 Retrived from https://doi.org/10.1016/B978-0-12-819527-7.00021-2

Madalla, N. (2021), Farmers traits preferences for improved banana cultivars in Tanzania and Uganda. Retrived http://urn.kb.se/resolve?urn=urn:nbn:se:slu:epsilon-p-109524

Mariotti, A.,Zeng, N., Yoon, JH.,Artale, V., Navarra, A., Alpert, P.,Li, LZX. (2008), Mediterranean water cycle changes: transition to drier 21st century conditions in observations and CMIP3 simulations.Environmental Research Letters 3: 1-7. Retrived from https://doi.org/10.1088/17489326/3/4/044001

Marzougui, S. (2021), Allelic variations at the HvSNF2 and HvBM5 loci are associated with the heading date and growth habit of barley (Hordeum vulgare L.) under a semi-arid climate. Czech Journal of Genetics and Plant Breeding, 57(2), 76-79. Retrived from https://doi.org/10.17221/62/2020CJGPB

McCairns, R.J., Smith, S., Sasaki, M., Bernatchez, L. and Beheregaray, L.B., (2016), The adaptive potential of subtropical rainbowfish in the face of climate change: heritability and heritable plasticity for the expression of candidate genes. Evolutionary applications, 9(4), pp.531-545. Retrived from https://doi.org/10.1111/eva.12363

Medina, CP. (2012), Rice: crop breeding using farmer-led participatory plant breeding, Chap 11. In: Lammerts van Bueren ET, Myers JR (eds) Organic crop breeding. Wiley-Blackwell, Oxford, pp 191-202. Retrived from https://doi.org/10.1002/9781119945932.ch11 
Merrick, L. F., Lyon, S. R., Balow, K. A., Murphy, K. M., Jones, S. S., \& Carter, A. H. (2020), Utilization of evolutionary plant breeding increases stability and adaptation of winter wheat across diverse precipitation zones. Sustainability, 12(22), 9728.) Retrived from https://doi.org/10.3390/su12229728

Morran, L.T.,Parmenter, M.D. and Phillips, P.C. (2009), Mutation load and rapid adaptation favour outcrossing over self-fertilization. Nature 462: 350-352. Retrived from https://doi.org/10.1038/nature08496

Morrell, PL., Lundy, KE., Clegg, MT. (2003), Distinct geographic patterns of genetic diversity are maintained in wild barley (Hordeumvulgare ssp. spontaneum) despite migration. ProcNatlAcadSci USA 100:10812-10817. Retrived from https://doi.org/10.1073/pnas.1633708100

Morales-Castilla, I., de Cortázar-Atauri, I. G., Cook, B. I., Lacombe, T., Parker, A., van Leeuwen, C., ... \& Wolkovich, E. M. (2020), Diversity buffers winegrowing regions from climate change losses. Proceedings of the National Academy of Sciences, $\quad 117(6), \quad 2864-2869 . \quad$ Retrived from https://doi.org/10.1073/pnas.1906731117

Murphy, K., Lammera, D., Lyona, S., Cartera, B. and. Jones, S.S. (2005), Breeding for organic and low-input farming systems: An evolutionary-participatory breeding method for inbred cereal grains. Renewable Agriculture and Food Systems 20: 48-55. Retrived from https://doi.org/10.1079/RAF200486

Murphy, K.M., Carter, A.H. and Jones, S.S. (2013), Evolutionary breeding and climate change. In Genomics and breeding for climate-resilient crops (pp. 377-389). Springer Berlin Heidelberg. Retrived from https://doi.org/10.1007/978-3642-37045-8_9

Mustafa, M. A., Mayes, S., \& Massawe, F. (2019), Crop diversification through a wider use of underutilised crops: A strategy to ensure food and nutrition security in the face of climate change. In Sustainable solutions for food security (pp. 125-149). Retrived from https://doi.org/10.1007/978-3-319-77878-5_7

Nelson, GC., Rosegrant, MW., Koo, J., Robertson, R., Sulser, T., Zhu, T., Ringler, C., Msangi, S., Palazzo, A., Batka, M., Magalhaes, M., Valmonte-Santos, R., Ewing, M., Lee, D. (2009), Climate change impact on agriculture and costs of adaptation. Food policy report.International Food Policy Research Institute, Washington, DC.

Nevo, E (2011), Triticum. In: Kole C (ed) Wild crop relatives: genomic and breeding resources, cereals. Springer, Berlin, pp 407-456. doi:10.1007/978-3-64214228-4_10. Retrived from https://doi.org/10.1007/978-3-642-142284 10

Newton, AC., Begg, GS., Swanston, JS. (2009), Deployment of diversity for enhanced crop function. Ann ApplBiol 154:309-322. Retrived from https://doi.org/10.1111/j.1744-7348.2008.00303.x

Pankin, A., Altmüller, J., Becker, C., \& von Korff, M. (2018), Targeted resequencing reveals genomic signatures of barley domestication. New Phytologist, 218(3), 1247-1259. Retrived from https://doi.org/10.1111/nph.15077

Page, A. M., \& Chapman, M. A. (2021), Identifying genomic regions targeted during eggplant domestication using transcriptome data. Journal of Heredity. Retrived from https://doi.org/10.1093/jhered/esab035 
Peng, J.H., Sun, D. and Nevo, E., (2011), Domestication evolution, genetics and genomics in wheat.Molecular Breeding, 28(3), p.281. Retrived from https://doi.org/10.1007/s11032-011-9608-4

Pecl, G. T., Araújo, M. B., Bell, J. D., Blanchard, J., Bonebrake, T. C., Chen, I. C., ... \& Williams, S. E. (2017), Biodiversity redistribution under climate change: Impacts on ecosystems and human well-being. Science, 355(6332). Retrived from https://doi.org/10.1126/science.aai9214

Phillips, S.L., Wolfe, M.S.( 2005), Centenary review: Evolutionary plant breeding for low input systems. J. Agric. Sci.140, 1-10.

Pinto, JG., Ulbrich, U., Leckebusch, GC.,Spangehl, T., Reyers, M., Zacharias, S. (2007), Changes in storm track and cyclone activity in three SRES ensemble experiments with the ECHAM5/MPI-OM1 GCM. Climate Dynamics 29: 195210. Retrived from https://doi.org/10.1007/s00382-007-0230-4

Pingali, P. L. (2017), The Green Revolution and crop biodiversity. In Routledge Handbook of Agricultural Biodiversity (pp. 213-223). Routledge. Retrived from https://doi.org/10.4324/9781317753285-13

Pixley, K.V. (2006), Hybrid and Open-Pollinated Varieties in Modern Agriculture.ArnelHallauer International Symposiumon Plant Breeding, Mexico, 17-22 August 2003, 234-250. Retrived from https://doi.org/10.1002/9780470752708.ch17

Pourkheirandish, M. and Komatsuda, T. (2007), The importance of barley genetics and domestication in a global perspective. Annals of Botany, 100(5), 9991008. Retrived from https://doi.org/10.1093/aob/mcm139

Saba M., Abu hammour W. and Aljaafreh S. (2014), Climate change and drought atlas for Jordan. International Center for Agricultural Research in the Dry Area.

Salamini, F., Özkan, H., Brandolini, A., Schäfer-Pregl, R., Martin, W. (2002), Genetics and geography of wild cereal domestication in the Near East. Nat Genet Rev 3:429-441. Retrived from https://doi.org/10.1038/nrg817

Schlaepfer, D. R., Braschler, B., Rusterholz, H. P., \& Baur, B. (2018), Genetic effects of anthropogenic habitat fragmentation on remnant animal and plant populations: a meta-analysis. Ecosphere, 9(10), e02488. Retrived from https://doi.org/10.1002/ecs2.2488

Schulze, E.D. (1988), Adaptation mechanisms of non cultivated arid-zone plants: useful lesson for agriculture? In Drought Research Priorities for the Dryland Tropics, ER Bidinger and C. Johansen (eds.). Patancheru, India: ICRISAT.

Serpolay-Besson, E., Giuliano, S., Schermann, N. and Chable, V. (2014), Evaluation of evolution and diversity of maize open-pollinated varieties cultivated under contrasted environmental and farmers' selection pressures: a phenotypical approach. Open Journal of Genetics, 4(02), 125. Retrived from https://doi.org/10.4236/ojgen.2014.42014

Sintayehu, D. W. (2018), Impact of climate change on biodiversity and associated key ecosystem services in Africa: a systematic review. Ecosystem health and sustainability, 4(9), 225-239. Retrived from https://doi.org/10.1080/20964129.2018.1530054

Simmonds, NW. (1991), Selection for local adaptation in a plant breeding programme. TheorAppl Genet 82:363-367. Retrived from https://doi.org/10.1007/BF02190624 
Soliman,K.M. and Allard, R.W. (1991), Grain yield of composite cross populations of barley: Effects of natural selection. Crop Science 31:705-708. Retrived from https://doi.org/10.2135/cropsci1991.0011183X003100030032x

Sthapit, BR., Joshi, KD.,Witcombe, JR. (1996), Farmer participatory crop improvement. III. Participatory plant breeding, a case study for rice in Nepal. ExpAgric 32:479-496. Retrived from https://doi.org/10.1017/S001447970000154X, https://doi.org/10.1017/S0014479700003823

Suneson, C.A. (1956), An Evolutionary Plant Breeding Method 1. Agronomy Journal, 48(4), 188-191. Retrived from https://doi.org/10.2134/agronj1956.00021962004800040012x

Suneson, C. A. (1969), Evolutionary Plant Breeding 1. Crop Science, 9(2), 119-121. Retrived from https://doi.org/10.2135/cropsci1969.0011183X000900020001x

Thapa, DB., Mudwari, A., Basnet, RK., Sharma, S., Ortiz-Ferrara, G., Sharma, B., Murphy, K. (2009), Participatory varietal selection of wheat for microniches of Kathmandu valley. J Sustain Agric 33:745-756. Retrived from https://doi.org/10.1080/10440040903221185

Torricelli, R., Ciancaleoni, S. and Negri, V. (2014), Performance and stability of homogeneous and heterogeneous broccoli Brassica oleracea L. var. italicaPlenck varieties in organic and low-input conditions.Euphytica 199, 385-395. Retrived from https://doi.org/10.1007/s10681-014-1139-8

Ullrich, S.E. (2010), Barley: Production, improvement, and uses (Vol. 12). John Wiley \& Sons.

Wang, X., Tang, H., \& Paterson, A. H. (2011), Seventy million years of concerted evolution of a homoeologous chromosome pair, in parallel, in major Poaceae lineages. The Plant Cell, 23(1), 27-37. Retrived from https://doi.org/10.1105/tpc.110.080622

Willcox, G. (2005), The distribution, natural habitats and availability of wild cereals in relation to their domestication in the Near East: multiple events, multiple centres. Vegetation History and Archaeobotany, 14(4): 534-541. Retrived from https://doi.org/10.1007/s00334-005-0075-x

Witcombe, JR., Joshi, A., Goyal, SN. (2003), Participatory plant breeding in maize: a case study from Gujarat, India. Euphytica 130:413-422. Retrived from https://doi.org/10.1023/A:1023036730919

Wright, S. I., Kalisz, S., \& Slotte, T. (2013), Evolutionary consequences of selffertilization in plants. Proceedings of the Royal Society B: Biological Sciences, 280(1760), 20130133. Retrived from https://doi.org/10.1098/rspb.2013.0133

Yang, T., Ding, J., Liu, D., Wang, X., \& Wang, T. (2019), Combined use of multiple drought indices for global assessment of dry gets drier and wet gets wetter paradigm. Journal of Climate, 32(3), 737-748. https://doi.org/10.1175/JCLI-D-18-0261.1. 